\title{
Weather based warning systems for bean angular-leaf-spot and anthracnose
}

\author{
Erlei Melo Reis ${ }^{1,2}$ e Marta Maria Casa Blum ${ }^{3}$
}

${ }^{1}$ Faculdade de Agronomia e Medicina Veterinária, Mestrado em Agronomia, Universidade de Passo Fundo, CP 611, CEP 99001-970 - Passo Fundo, RS. ${ }^{2}$ Bolsista do CNPq. ${ }^{3}$ Universidade Regional Integrada do Alto Uruguai e das Missões - URI Campus de Erechim. Autor para correspondência: Erlei Melo Reis (erleireis@upf.br) Data de chegada: 09/02/2011. Aceito para publicação em: 23/04/2012.

\section{ABSTRACT}

Reis, E. M. e Blum, M. M. C. Weather-based warning systems for bean angular leaf spot and anthracnose. Summa Phytopathologica, v.38, n.3, p.228-231, 2012.

Data available in the literature were used to develop a warning system for bean angular leaf spot and anthracnose, caused by Phaeoisariopsis griseola and Colletotrichum lindemuthianum, respectively. The model is based on favorable environmental conditions for the infectious process such as continuous leaf wetness duration and mean air temperature during this subphase of the pathogen-host relationship cycle. Equations published by DALLA PRIA (1977) showing the interactions of those two factors on the disease severity were used. Excell spreadsheet was used to calculate the leaf wetness period needed to cause different infection probabilities at different temperature ranges. These data were employed to elaborate critical period tables used to program a computerized electronic device that records leaf wetness duration and mean temperature and automatically shows the daily disease severity value (DDSV) for each disease. The model should be validated in field experiments under natural infection for which the daily disease severity sum (DDSS) should be identified as a criterion to indicate the beginning and the interval of fungicide applications to control both diseases.

Additional keywords: Colletotrichum lindemuthianum, Phaeoisariopsis griseola, Phaseolus vulgaris, plant disease forecasting.

\section{RESUMO}

Reis, E. M. e Blum, M. M. C. Modelos climáticos de aviso para a mancha-angular e antracnose, em Feijoeiro. Summa Phytopathologica, v.38, n.3, p.228-231, 2012.

Utilizando-se dados disponíveis na literatura, elaborou-se um sistema de previsão da mancha angular e da antracnose do feijoeiro, causadas por Phaeoisariopsis griseola e por Colletotrichum lindemuthianum respectivamente. O modelo baseia-se nas condições ambientais favoráveis ao processo infeccioso, como a duração do molhamento foliar contínuo e a temperatura média do ar durante essa subfase do ciclo das relações patógeno-hospedeiro. Tomaram-se as equações geradas no trabalho de DALLA PRIA (1977), que representam as interações desses dois fatores sobre a severidade das doenças. Com auxílio da planilha eletrônica Excell, calculou-se a duração do molhamento foliar para causar diferentes probabilidades de infecção em diferentes faixas térmicas. Com esses dados foram elaboradas tabelas de períodos críticos e utilizadas na programação de um aparelho eletrônico, computadorizado que registra a duração do molhamento, a temperatura média e automaticamente mostra o valor diário de severidade (VDS) para cada uma das doenças. O modelo deve ser validado em experimentos conduzidos no campo sob infecção natural tendo-se identificada a soma dos valores diários de severidade (SVDS) como critério indicador para o início e intervalo das aplicações de fungicidas para o controle das duas doenças.

Palavras-chave adicionais: Colletotrichum lindemuthianum, Phaeoisariopsis griseola, Phaseolus vulgaris, previsão de doenças.

In Brazil, bean crop was grown in an area of about 4.3 million hectares in the 2009/10 growing season, with an estimated production of 1.33 million tons and 0.75 t.ha ${ }^{-1}$ yield average (2).

The main factors limiting bean productivity are fungal diseases complex, bacterial and viral infections $(8,9)$. Among fungal diseases the most widespread ones causing extensive damage are angular leaf spot caused by Phaeoisariopsis griseola (Sacc.) Ferraris and anthracnose caused by Colletotrichum lindemuthianum (Sac. \& Magn.) Br \& Cav. (7, 8). Control measures are focused on development and use of resistant cultivars, production of healthy seeds and their treatment with fungicides, crop rotation and chemical control of above- ground plant organs (7).

Use of fungicides is an effective control measure but increases the production cost, which may compromise economic and environmental sustainability (14). There are many criteria for timing fungicide application, and little has been done to rationalize their use. One way to prevent economic losses and environmental negative impact is the improvement of chemical control efficiency through the development of disease forecasters as indicators to time spraying applications (1).

Several papers have been published concerning the effect of the environment on the infection process and on the development of several diseases in various hosts. One of them was conducted with 
rust, anthracnose and angular leaf spot of bean by DALLA PRIA (6) and BACHI (3). In these studies the interactions of leaf wetness duration and temperature on the severity of those three diseases were studied. Nevertheless, those authors do not discuss the possibility of using their data for the development of a warning system.

Disease warning systems are based on the presence in time and space of the three disease determining factors: host, pathogen and environment. Few predictive models are based on inoculum monitoring in relation to the disease onset (4) because they are very laborious. Most available systems are based on the weather requirements for inoculum multiplication $(11,13)$ and infection $(10,12,16)$.

The present work was conducted considering the occurrence frequency, the damage caused by two diseases and the need to rationalize the use of chemical control to achieve economic and environmental sustainability of bean crop.

This study aimed to develop warning systems for bean angular leaf spot and anthracnose, based on the weather model.

Basic data for this study were obtained from the publication of DALLA PRIA (6) where the equations for the interactions between temperature and leaf wetness duration on the severity of angular leaf spot and anthracnose were generated.

For each disease equation, in the spreadsheet Excel 6.0 (Microsoft 2000), using angular leaf spot and anthracnose desired intensities expressed as severity (\%) and temperature, the wetness duration (WD) was taken as unknown variable and the duration needed to cause the desired disease intensity was estimated for each disease. Temperature effects were calculated at $1.0^{\circ} \mathrm{C}$ intervals and wetness duration at 1.0 $\mathrm{h}$ intervals.
Similarly to the study of Madden et al. (12), who developed critical period tables based on the weather model to predict Alternaria solani Sorau. in tomato, we assigned five arbitrary values to indicate the daily probability of occurrence of different disease severities: 0 (no symptoms); $1=1 " 4 \%$ severity; $2=5 " 9 \%$ severity, $3=10 " 14 \%$ severity; $4=15 " 20 \%$ severity; and (-) severity not reached for both diseases. The infectious process (inoculum production, release, transport, deposition, and host penetrations) may be a daily phenomenon, hence the name daily disease severity value (DDSV).

Based on the interactions of Tables 2 and 5, a data logger unit equipped with electronic sensors that measures temperature and leaf wetness duration at five-minute intervals and automatically records DDSV and their sum (DDSS) (Colpam 40, www.elomed.com.br) was programmed.

The weather-model forecaster is based on the effect of the environment on the infectious process. Once the spores are deposited on the infection sites they respond to stimuli that are environmental signals. The main stimuli are water (leaf wetness) and temperature. The response of spores to wetness is obligatory and irreversible, reacting to the stimulus through germination (17). The weather model forecasts infection (germination, germ tube growth, penetration of the host and establishment of parasitism) (5). An infection is successful when the wetting period (WP) is of sufficient duration, at a mean favorable temperature for host penetration. Zadoks \& Schein (17) termed this interaction as critical period (CP). Therefore, after the occurrence of a $\mathrm{CP}$, the leaf surface may dry and pathogens will continue their life cycle.

Most forecasting systems based on the weather model use CP

Table 1. Interactions between leaf wetness duration (WD) and mean air temperature $\left(\mathrm{T}^{\circ} \mathrm{C}\right)$ to obtain daily disease severity values (DDSV) of bean angular leaf spot, caused by Phaeoisariopsis griseola, cultivar Carioca

\begin{tabular}{|c|c|c|c|c|c|c|c|c|}
\hline \multirow{3}{*}{$\mathbf{T}^{\circ} \mathbf{C}$} & \multicolumn{8}{|c|}{ Daily disease severity values (DDSV) ${ }^{\mathrm{z}}$} \\
\hline & $\mathbf{0}$ & \multicolumn{2}{|r|}{1} & \multicolumn{2}{|c|}{2} & \multicolumn{2}{|c|}{3} & 4 \\
\hline & \multicolumn{8}{|c|}{ Leaf wetting duration (WD) } \\
\hline $5-9$ & $<22.8$ & 22.9 & 26.3 & 25.7 & 29.6 & 29.7 & 30.6 & - \\
\hline $10-14$ & $<22.1$ & 22.1 & 24.2 & '24.3 & 26.4 & 26.5 & 28.6 & $>28.6$ \\
\hline $15-19$ & $<21.8$ & 21.9 & 23.9 & 24.0 & 25.8 & 25.9 & 27.5 & $>27.5$ \\
\hline $25-30$ & $<22.5$ & 22.5 & 24.0 & 24.1 & 26.6 & 24.7 & 27.8 & $>27.8$ \\
\hline
\end{tabular}

$\left({ }^{z}\right)$ - DDSV: $0=$ zero severity (no symptoms); $1=$ severity from 1 to $4 \% ; 2=$ severity 5 from $9 \% ; 3=$ severity from 10 to $14 \% ; 4=$ severity from 15 a $20 \%$; (-) severity not reached.

Table 2. Interactions between leaf wetness duration (WD) and mean air temperature $\left(\mathrm{T}^{\circ} \mathrm{C}\right)$ to obtain daily disease severity values (DDSV) of bean angular leaf spot, caused by Phaeoisariopsis griseola, cultivar Rosinha

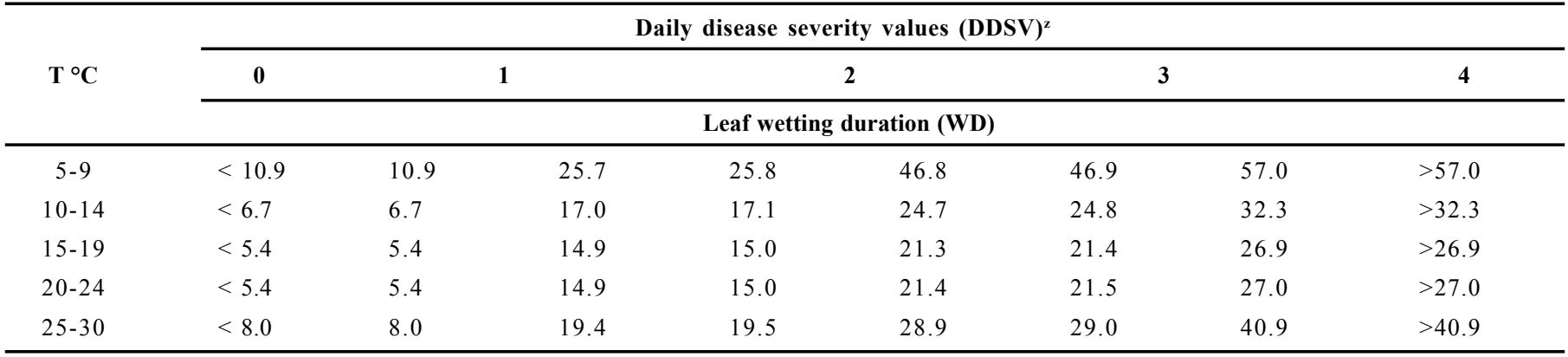

( $\left.{ }^{2}\right)$ DDSV: $0=$ zero severity (no symptoms); $1=$ severity from 1 to $4 \% ; 2=$ severity 5 from $9 \% ; 3=$ severity from 10 to $14 \% ; 4=$ severity from 15 a $20 \% ;(-)$ severity not reached. 
Table 3. Interactions between leaf wetness duration (WD) and mean air temperature $\left(\mathrm{T}^{\circ} \mathrm{C}\right)$ to obtain daily disease severity values (DDSV) of bean anthracnose, caused by Colletotrichum lindemuthianum, cultivar Rosinha

\begin{tabular}{|c|c|c|c|c|c|c|c|c|}
\hline \multirow{3}{*}{$\mathbf{T}^{\circ} \mathbf{C}$} & \multicolumn{8}{|c|}{ Daily disease severity values (DDSV) ${ }^{x}$} \\
\hline & $\mathbf{0}$ & \multicolumn{2}{|r|}{1} & \multicolumn{2}{|c|}{2} & \multicolumn{2}{|c|}{3} & \multirow[t]{2}{*}{4} \\
\hline & \multicolumn{7}{|c|}{ Leaf wetting duration (WD) } & \\
\hline $5-9$ & 18.1 & 18.1 & 21.0 & 21.1 & 22.7 & - & - & - \\
\hline $10-14$ & 17.4 & 17.4 & 18.6 & 18.7 & 19.6 & 19.7 & 21.0 & $>21.0$ \\
\hline $15-19$ & 17.4 & 17.4 & 18.6 & 18.7 & 23.8 & $23, .9$ & 20.8 & $>20.8$ \\
\hline $25-30$ & 18.0 & 18.0 & 20.3 & 20.4 & - & - & - & - \\
\hline
\end{tabular}

$\left({ }^{z}\right)$ DDSV: $0=$ zero severity (no symptoms); $1=$ severity from 1 to $4 \% ; 2=$ severity 5 from $9 \%$; $3=$ severity from 10 to $14 \%$; $4=$ severity from 15 a $20 \% ;(-)$ severity not reached.

Table 4. Interactions between leaf wetness duration (WD) and mean air temperature $\left(\mathrm{T}^{\circ} \mathrm{C}\right)$ to obtain daily disease severity values (DDSV) of bean anthracnose, caused by Colletotrichum lindemuthianum, cultivar Carioca

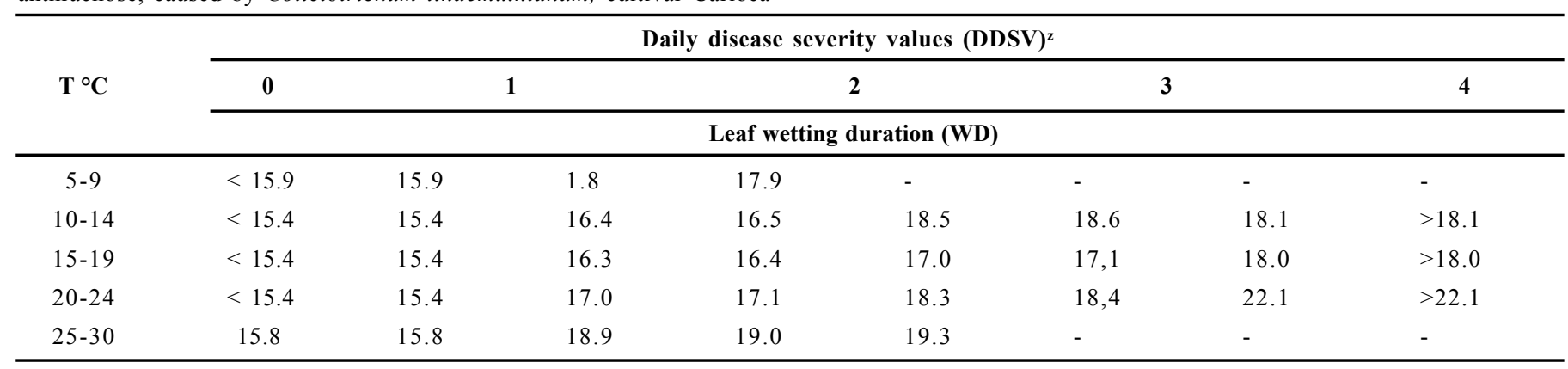

( $\left.{ }^{z}\right)$ DDSV: $0=$ zero severity (no symptoms); $1=$ severity from 1 to $4 \% ; 2=$ severity 5 from $9 \%$; $3=$ severity from 10 to $14 \% ; 4=$ severity from 15 a $20 \% ;(-)$ severity not reached.

Table 5. Interactions between leaf wetness duration (WD) and mean air temperature $\left(\mathrm{T}^{\circ} \mathrm{C}\right)$ to obtain daily disease severity values (DDSV) of bean anthracnose, caused by Colletotrichum lindemuthianum

\begin{tabular}{|c|c|c|c|c|c|c|c|c|}
\hline \multirow{2}{*}{$\mathbf{T}^{\circ} \mathbf{C}$} & \multicolumn{8}{|c|}{ Daily disease severity (VDS) ${ }^{z}$} \\
\hline & \multicolumn{8}{|c|}{ Leaf wetting duration (WD) } \\
\hline $5-9$ & $<15.9$ & 15.9 & 17.7 & 17.8 & - & - & - & - \\
\hline $10-14$ & $<15.4$ & 15.4 & 16.8 & 16.9 & 19.6 & 19.7 & 20.7 & $>20.7$ \\
\hline $15-19$ & $<15.4$ & 15.4 & 16.1 & 16.2 & 19.4 & 19.5 & 20.5 & $>20.5$ \\
\hline $25-30$ & $<15.8$ & 15.8 & 17.0 & 17.1 & 19.3 & $>19.3$ & - & - \\
\hline
\end{tabular}

$\left({ }^{z}\right)$ DDSV: $0=$ zero severity (no symptoms); $1=$ severity from 1 to $4 \% ; 2=$ severity 5 from $9 \%$; $3=$ severity from 10 to $14 \% ; 4=$ severity from 15 a $20 \% ;(-)$ severity not reached.

tables to predict infection. As a population, fungal spores do not respond synchronously to germination, wetness duration and temperature, which results in different infection proportions and therefore different disease severity based on their response to those environmental factors. Each individual has a WP and temperature requirement to successfully complete the infection (15).

Moreover, different disease levels can be obtained by using different inoculum concentrations or different temperatures and/or leaf wetness durations. The interaction of leaf wetness duration with the mean temperature during this period is the fundament of disease forecasting systems based on the effect of the environment on the infectious process and thus called environmental model that provides infection (10).

According to Sutton (15), the effects of interactions between temperature and wetness duration on the infection, obtained under controlled conditions, can be distorted in the field. In this case the factors that compromise the infection efficiency and do not accurately reflect what occurred under controlled conditions are: (a) variations in the temperature fluctuation in the canopy, (b) small discontinuance in wetness duration, (c) different inoculum densities, (d) spore viability (\% germination), (e) host predisposition (leaf age), (e) presence of nutrients and pesticides on the phylloplane, and (f) biological activity of living antagonistic organisms on the phylloplane. Therefore, the absolute frequency of infection cannot be predicted. To partly solve 
these problems, researchers have divided the infection response data into different probability values for infection occurrence or daily disease severity (DDSV). The DDSVs proposed here are: 0, 1, 2, 3 and 4 (Tables 1 to 5), because wetting is a daily phenomenon. The future infection depends on the efficiency of the spore infection, which in turn is commanded by CPs.

\section{System for angular leaf spot}

Table 1 shows the interactions of mean temperature and hours of continuous wetness duration (WD) to produce DDSV of 0, 1, 2, 3 and 4 for angular leaf spot in bean cultivar Carioca. The data in this Table have small WD amplitude. The shortest WD was $21.8 \mathrm{~h}$ wetting, and the longest one was $28.6 \mathrm{~h}$. In a forecast system, it is desirable that the tables of critical periods for increased safety have a wide WD range. Table 1 therefore does not meet this criterion and therefore may have low rate to accurately predict infection in the field.

Table 2 was obtained by using the data from the experiment with cultivar Rosinha. The data in this Table have greater WD amplitude. The shortest WD was $5.4 \mathrm{~h}$ and the longest one was $30.7 \mathrm{~h}$. Therefore, this Table was chosen to be tested for the possibility of showing a higher success probability in predicting the infection under field conditions.

\section{System for anthracnose}

Also based on the principle of having a model with greater WD range, data from Tables 3 and 4 were integrated. WD data corresponding to $1 \%$ severity were taken from Table 3 and WD corresponding to 2, 3 and 4 severity from Table 4 in order to generate Table 5 and were used for the anthracnose system validation.

Critical periods are different for each pathosystem; thus, DDSV tables are also different for each fungal species in a given host.

Therefore, it is suggested that Tables 2 and 5 may be used as basis to forecast bean angular leaf spot and anthracnose, respectively.

Field experiments are being conducted at University of Passo Fundo and Centro Agro Veterinário - UDESC, Lages - Santa Catarina State, Brazil, to identify DDSS values in which diseases have their onset when the weather monitoring starts from crop emergence.

\section{ACKNOWLEDGMENT}

The authors are grateful to Syngenta for the scholarship awarded to the second author during the systems development and validation.

\section{REFERENCES}

1. Campbell, C. L.; Madden, L. V. Introduction to plant disease epidemiology. New York: Wiley, 1990. 532 p.

2. CONAB. Previsão e acompanhamento da safra 2009/10. www.conab.gov.br. 2010.

3. Bacchi, L.M.A. Quantificação de parâmetros monocíclicos relacionada a epidemias no sistema Uromyces appendiculatusfeijoeiro. 1999. 99 p. Tese (Doutorado em Fitopatologia) - Escola Superior de Agricultura "Luiz de Queiroz" - Universidade de São Paulo, Piracicaba, 1999.

4. Berger, R. D. A celery early blight spray program based on disease forecasting. Florida Agricultural Experiment Stations. Journal Series n. 3369, p.107-111, 1969.

5. Butt, D. J.; Royle, D. J. The importance of terms and definitions for conceptually unified epidemiology. In: Palti, J.; Krans, J. (Ed.) Comparative epidemiology: a tool for better disease management Wageningen: Centre for Agricultural Publishing and Documentation, 1980. p. 29-45.

6. Dalla Pria, M. Quantificação de parâmetros monocíclicos da antracnose (Colletotrichum lindemuthianum) e da mancha angular (Phaeoisariopsis griseola) do feijoeiro. 1997. 82 p. (Tese Doutorado em Fitopatologia). ESALQ-USP-Piracicaba; 1997.

7. EMBRAPA <http://cnpaf.embrapa/feijao/sistemadeproducao > Acessado em 29 de novembro de 2011.

8. Empresa de pesquisa agropecuária (EPAGRI). Recomendações técnicas para a cultura do feijão em Santa Catarina. Florianópolis; 1997.70 p. (Sistemas de Produção, 29).

9. Hall, R. Compendium of bean diseases. Saint Paul: APS Press, 1994. $73 \mathrm{p}$

10. Krause, R. A.; Massie, L. B. Predictive systems: modern approaches to disease control. Annual Review of Phytopathology, Palo Alto, v. 13, p. 31-47, 1975.

11. Lalancette, N.; Ellis, M. A.; Madden, L. V. A quantitative model for describing the esporulation of Plasmopara viticola on grape leaves Phytopathology, St. Paul, v.78, n. 10, p. 1316-1321, 1988.

12. Madden, L.; Pennypacker, S. P.; MacNab, A. A. FAST, a forecast system for Alternaria solani on tomato. Phytopathology, St. Paul, v. 68, n. 9, p. 1354-1358, 1978.

13. Mendes, C. S.; Reis, E. M .; Sônego, O. R. Flutuação anual de esporangiosporos de Plasmopara viticola, no ar, em Bento Gonçalves, RS. Summa Phytopthologica, Botucatu, v. 29, n. 4, p. 362-364, 2003.

13. Munford, J. D.; Norton, G. A. Economics of decision making in pest management. Annual Review of Entomology, Palo Alto, v. 29, p.157-174, 1984.

14. Sutton, J. C. Predictive value of weather variables in the epidemiology and management of foliar diseases. Fitopatologia Brasileira, Brasília, DF, v. 12, n. 4, p. $305-312,1988$.

15. Wallin, J. R. Summary of recent progress in predicting late blight epidemics in United States and Canada. American Potato Journal, v. 39, p. 306-312, 1962

16. Zadoks, J. C.; Schein, R. D. Epidemiology and plant disease management. New York: Oxford University Press, 1979. 427 p. 